\title{
Prophets praying for, or preying on people's faith: A reflection on prophetic ministry in the South African context
}

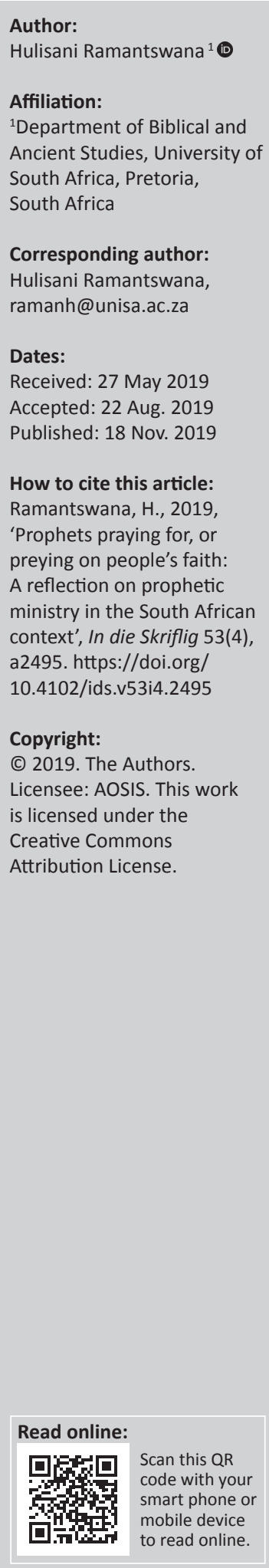

In mainline churches, the ministry of prophecy or the prophetic ministry involves the proclamation of the gospel. This, in turn, is related to the every-believer ministry. However, there is now a resurgence of the prophetic ministry as a special office as evidenced by the establishment of neo-prophetic churches. This article argues that neo-prophetic churches are tapping into people's longing for the fresh divine word to speak directly into their personal situations. The article also probes whether neo-prophets in the prophetic activities are not also preying on people's faith.

Keywords: Prophets; Prophecy; Neo-Prophetic Churches; Threefold Office; Prophetic Theology; Prophetic Office; Traditional Churches; Pentecostal; Charismatic.

\section{Introduction}

Dunn (2016:39) observes, 'Across the Global South, contemporary Christian theology is grappling with the best way to understand and respond to the rise of neo-Pentecostalism and the associated emphasis on charismatic experience.' Of the charismatic experiences, there is a resurgence of living prophecy. De Gruchy (2016) notes that throughout history, there is a tendency to silence and suppress prophetic ministry, but under the right circumstances it has continued to resurface repeatedly, and in recent times its presence is particularly felt within those churches that embrace charismatic gifts and those that embrace a dispensational interpretation of the Bible. De Gruchy argues that, within Pentecostal-Charismatic churches and dispensational churches, the prophetic ministry has been executed with a particular focus on reading the signs of the end times and the support of Christian Zionism. However, in neo-Pentecostalism, which is of interest in this study, the focus is on the person, the prophet, who utters prophetic utterances, delivers, heals and performs miracles. It is becoming common in the (South) African context to speak of 'prophetic churches' or 'neo-prophetic churches' - which are churches that revolve around their prophets as the ones through whom prophetic charisma is manifested (Omenyo 2011). The resurgence of prophetic charisma is a reality in our context; yet, it also presents challenges considering the practices within the current prophetic churches, which draws suspicion as to whether some of the prophets are praying for, or preying on people's longing for a personal divine word.

Within the South African context, the Commission for the Promotion and Protection of the Rights of Cultural, Religious and Linguistic Communities (CRL Commission 2016), due to the complaints received, went on to investigate what were considered unusual practices of pastors or prophets who instructed congregants to eat things such as grass and snakes and to drink petrol, and who also promised them things such as healing, miracles and blessing - practices which go on without accountability. The unusual practices and promises of things such as healing, miracles, blessings, et cerera, are not things that characterise all church circles. However, they are somewhat associated with prophetic churches in which people are willing to submit to whatever the prophet or pastors instruct (see Kgatle 2017). The aim of this study is not to question or challenge the existence of neo-prophetic churches, but to explore the role of prophetic ministry, considering the way that it is viewed in mainline churches, the ecumenical church and in the neo-Pentecostal churches.

\section{Prophetic ministry in mainline churches: Universal participation of the church in the prophetic office}

Prophetic ministry within the mainline churches is intertwined with the threefold office of Jesus as the 'Christ' - priest, prophet and king - which also came to be applied to the believers or the church. The application of threefold office to believers goes as far back as the early church. 
During the 3rd century AD or CE, in The Apostolic Tradition of Hippolytus of Rome, there is the following reference to the liturgical act of anointing new believers with oil by the bishop in the church (as translated in Stewart-Sykes 2001:76):

O God, sanctify this oil: Grant holiness to all who use it and who receive it, and as you anointed kings, priests and prophets, so may it give strength to all who consume it and to all who use it.

Beal (2011) notes that Hippolytus' Apostolic Tradition does not refer to the act of baptism, which we find during the 5th century in John Chrysostom's 'Third Homily on the Second Letter to the Corinthians'. For Chrysostom, the offices of priest, prophet and king in Old Testament (OT) times applied to specific individuals. However, within the context of the church, they apply to all believers. As Beal (2011:92) points out:

Chrysostom did not describe the offices with reference to Christ, who is mentioned only in connection with the office of priesthood. Rather, he described them in terms of their continuity with and distinction from the anointed offices of Israel.

However, it was in the 5th century that bishop Fastidius drew the correspondence between Christ's anointing and the anointing of a believer, stating (quoted in De Boer 2013:2):

And so great was the mystery of this anointing that not all in the Jewish people proved worthy to receive that; rather, few of the many. And so it has been until the coming of our Lord Jesus Christ, whom God has 'anointed with the oil of gladness before your companions' (Ps 47:7). But from that time those who have faith and are purified by the sanctification that baptism, not some, such as it had been earlier under the law, but all have been anointed prophets, priests, and kings.

Within the Roman Catholic Church, following the Council of Trent in 1566, the church, in line with the patristic tradition, confessionally linked the threefold office (munus triplex) of Jesus with the title Messiah. It should be noted, however, that at that point, no attempts were made to link the threefold office of Christ with the believer. It was in the wake of Vatican II that the threefold office of Christ was equated with the ministry of the church or believers. ${ }^{1}$ In the Catechism of the Catholic Church, Article 9 of the Apostolic Creed ('I believe in the holy catholic church') the church, as God's people is, among other things, explained as a priestly, prophetic and royal people. As such, the people of God 'participates in these three offices of Christ and bears the responsibilities for mission and service that flow from them'. Believers participate in the prophetic role through the deepening of their understanding and of becoming witnesses of Christ in the world. Prior to Vatican II, the Roman Catholic Church did not theologically or confessionaly link the three offices of Christ with the ministry of the church as was the case in Protestantism (Rush 2003). However, as it now stands, threefold offices are understood in terms of sensus fide fidelium [sense of faith on the part of the faithful], which implies that every believer on the basis of faith in the Lord Jesus Christ and the anointing through the Holy Spirit, participates in the three offices (Rush 2003). This further implies that there is universal participation of believers, both ordained and laity, in the prophetic office. The ordained ministers, however, also have a role of building up the laity in the exercise of their offices.

While the Roman Catholic Church confessionally affirms the threefold office of Christ, this category did not always affirm their ecclesiology. However, in the Protestant churches, the threefold office was confessionally linked with ecclesiology. The Protestant confessional view on the threefold office is expressed in the Heidelberg Catechism, ${ }^{2}$ Lord's Day 12 in which the following questions are dealt with: Question 31 ' Why is he [Jesus] call Christ, that is anointed one?' and Question 32, 'Why are you called a Christian?' For the authors of the Heidelberg Cathecism, believers' anointing is modelled after Christ's anointing and therefore, just as Jesus is anointed through the Holy Spirit as chief Prophet, only High Priest, eternal King, believers share in this anointing, as well as they are also anointed as prophets, priests and kings. However, in excercising their office, believers do so in light of what Christ had already achieved for them. ${ }^{3}$

Luther advanced the theological concept of priesthood of all believers, which implies that all believers, not merely those ordained in a particular office in the life of the church, have the right to serve. However, it was other Reformers such as Andreas Osiander, Martin Bucer, John Calvin, Zacharius Ursinus and Caspar Oliveanus who propounded the threefold office of Christ. Osiander, as Sherman (2004) notes, was the first among the Reformers to expound on the concept Christ by drawing a connection with the OT and also providing the theological relevance for the believers. Osiander wrote (quoted in Pannenberg 1977:213):

Since Christ is thus is called an Anointed One and only the prophets, kings, and high priests were anointed, one notes well that all three of these offices rightly belong to him: the prophetic office, since he alone is our teacher and master, Matt. 22:8ff.; the authority of the king, since he reigns forever in the house of Jacob, Luke 1:32ff.; and the priestly office, since he is a priest forever after the order of Melchizedek, Ps. 110:4. Thus it is his office that he is our wisdom, righteousness, sanctification, and redemption, as Paul testifies in 1 Cor., ch. 1.

An elaborated discussion on the threefold offices, mainly as they pertain to the believer, is found in Oliveanus's A Firm Foundation (1567). Our interest is more on Oliveanus' expansion on the office of prophet as it relates to the church. For Oliveanus (1995:44), God provides prophets in two ways: firstly, by raising ministers of the Word in the life of the church; and secondly, by working through all believers while they proclaim the Word although they do not hold the office in the life of the church. The equation of prophetic ministry with every believer implies that every believer has a prophetic responsibility. For Oliveanus (1995:52-53) believers can exercise their prophetic responsibility in three ways: (1) there is

2.The Heidelberg Catechism may be accessed online: https://www.heidelbergcatechism.com/pdf/lords-days/Heidelberg-Catechism.pdf

3.For a detailed discussion on Heidelberg Catechism, Lord's Day 12, see De Boer (2013). 
the public dimension in which a believer publicly praises and profess his or her faith; (2) sharing the gospel with all those who are under your care or serve under you ('servants'); and (3) sharing the gospel with the neighbours whenever opportunity presents itself. Thus, the prophetic office as universally applicable to every believer, amounts to sharing the Word with those outside the church and those inside the church, that is, the proclamation of the gospel to those outside the church and the teaching of those inside the church as a way of instructing and building up the faith.

In summary, the prophetic office within the mainline churches is a confessional matter linked to the threefold office of priest, prophet and king. However, the prophetic office is linked particularly with the ministry of the Word as exercised in a unique way by those who hold office in the life of the church and in a general or universal way, for it is every believer's responsibility to share the gospel with unbelievers - those outside the church, and with believers those already inside the church.

\section{The ecumenical church and prophetic theology in (South) Africa}

In the African context, from an ecumenical perspective, calls have been made for the church to exercise its prophetic role. The All Africa Conference of Churches (AACC), which is an ecumenical assembly of churches, from its inception in 1963, laid emphasis on the prophetic witness of the church. The AACC in 1974 defined the mission of the church as follows (AACC 1975:38):

The mission of the church is prophetic, and in serving it can accomplish by being engaged, involved and sensitive to the well-being of society. The church must be alive in the present in order to live better in the future.

The emphasis does not lie in the prophetic role of an individual, but on the community. It is the church, as a community of believers beyond the confessional and denominational confines, which is prophetic. As Kaunda (2018:1) notes, ' $[t]$ he specific focus on the prophetic witness is in keeping with ecclesiology ecumenism public dimensions and African notions of ecumenism which have been largely understood in prophetic terms'. Thus, the ecumenical church is able to rally around a common purpose and live out its prophetic role in the context of oppression, suffering, poverty and corruption. In so doing, the ecumenical church works towards an alternative reality of a just and equitable society.

In the South African context, during the colonial-apartheid era, there arose a need for what was deemed a prophetic theology. This was a time which, according to the Kairos theologians, called 'for a response from Christians that is biblical, spiritual, pastoral and, above all prophetic' (Leonard 2010:23). Such a prophetic theology was one born out of pain and suffering, considering the oppression and injustices faced by the black majority in South Africa. In De Gruchy's terms (2016), this is a theology that arose in the context of the struggle for justice, as those who crafted the Kairos document, listened to the cries of the ordinary people and therefore opted to offer a prophetic response which had as its preferential option the poor. Thus, during this time, the ecumenical church could not continue with ecclesiastical activities as usual while the ordinary people faced the situation of damnation.

The ecumenical church defined its prophetic theology as opposed to both 'state theology', which supported and legitimised the colonial matrix and apartheid, and 'church theology', which utilised principles such as reconciliation, negotiation, non-violence and peaceful solutions without a proper societal analysis and therefore failed to offer a proper response to the injustice and the oppression endured by the oppressed. Prophetic theology is not neutral; instead, it squarely faces life-denying realities, injustice and oppression in whatever form they come in pursuit of a just society. The ecumenical dimension allows for believers across all denominations to prophesy against the church when the church plays a role in perpetuating injustice and becomes complacent in the face of oppression.

The ecumenical dimension thus elevates prophecy beyond denominational divides, racial divides, cultural divides, et cetera, as believers from different denominations in unity exercise their prophetic role for the greater good of society. Pace De Kruijf's view (1994) that the prophetic approach to societal issues is no longer relevant in our contemporary context of liberal democracies and should be primarily concerned with the community of believers, the fact that liberal democratic states do not necessarily base their policies on Christian principles and values, implies that the church must fulfil its prophetic role as the conscience of society. De Villiers (2010) notes that in a democratic state such as we have in South Africa, religion still has a role to play and can influence public issues as well as government policies and legislation based on Christian values that may also be acceptable to non-Christians. I concur with the Kairos theologians that prophetic theology should be able to read the signs of the times and be able to offer proper responses at both local and global levels.

It should be noted, however, that, when the ecumenical church takes its role as a prophetic voice seriously, it should also expect pushback or backlash from the forces to whom the prophetic voice is addressed. During the heyday of colonialism and apartheid, the colonial-apartheid machinery was opposed to the critical prophetic voice of the church which came through prophetic figures such as Beyers Naudé, Peter Storey, Desmond Tutu, Allan Boesak, Frank Chikane, Smangaliso Mkhatshwa, Makhenkesi Stofile, Mvume Dandala, Peter Marais, Sipho Mzimela and Stanley Magoba (see Resane 2017; 2018).

It has often been noted that, since the dawn of democracy in South Africa, the ecumenical prophetic voice of the church has grown weak (Snyman 2016; Strydom 1997; 2000). For Kgatle (2018), there are three things which have contributed to the weakening of the prophetic voice: (1) those from the 
church who were at the cutting edge were absorbed into the new structures of the democratic government; (2) the church did not continue to maintain a critical distance, but it became co-opted by the state machinery; ${ }^{4}$ and (3) those who were at the cutting edge, failed to pass the baton to the younger generation. While the prophetic voice in the public arena might have weakened, new prophetic voices were emerging within the confines of the church, which had as its target, not so much the political and civil society, but the individual.

\section{Prophets in neo-prophetic churches}

In Pentecostal-Charismatic churches' prophetic ministry, unlike in the traditional churches where it is primarily associated with preaching, instruction and guidance, it is viewed as a spiritual gift (pneumatic charisma). This considers the biblical call in 1 Corinthians 14:1 (NIV): 'Follow the way of love and eagerly desire spiritual gifts, especially the gift of prophecy'. Prophecy as a gift, as Gee (1972) argues, has to do with 'divinely inspired utterance' and does not have to be despised in the life of the church as done by those who prefer the 'purely logical and didactic ministries' (see also Warrington 2008:83). This, however, as Gee would further argue, does not imply that there should be no guard against false prophesy or infallibility. There are other offices in the life of the church to complement and to safeguard the office of prophet.

Thus, prophecy within Pentecostal-Charismatic churches is not associated with the written Word of God as divine revelation, but rather with direct divine revelation from God as channelled through the prophet. As Palma (1970:11) states: 'The essential nature of prophecy is that of divine revelation given to the prophet which he in turn communicates to others.' For Wyane Grudem, a Pentecostal systematician, prophecy has two distincitive features, particularly in the New Testament: (1) prophecy is based on revelation and therefore, where there is no revelation, there is no prophecy; and (2) prophecy has to be proclaimed - mere revelation that is not proclaimed, is not prophecy (see Grudem 1999:143144). As Grudem (1999:143) argues, prophecy has to do with 'telling something that God has brought spontaneously to mind'.

The spontaneous prophecies do take various forms: (1) prophecy in terms of forth-telling, that is, a word or message received by the prophet to tell to an individual or a congregation (in terms of prophecies, especially those directed to individuals, a prophet may describe or tell events happening in the person who is being prophesied); and (2) prophecy in terms of fore-telling or prediction, that is, prophecies regarding what will happen in the future either positive or negative and predicting outcomes events. It should be noted, however, that much that has been written

\footnotetext{
4. Bentley (2013) notes that an organisation such as the South African Council of Churches (SACC): called for the church to be in a critical solidarity with the state. From this point of view, the church created a critical distance between itself and the From this point of view, the church created a critical distance between itself and the
state, so that it was close enough to the state to be a partner in transformation, but far enough removed to speak in criticism when needed.
}

about Pentecostalism, as Li Ming Dennis (2018) highlights, comes from the West, while the majority of Pentecostals are now found in Africa, Asia and Latin America. Therefore, there is a lack of empirical-theological studies that focus on prophetic movement in these contexts.

In the South African context, there has been an emergence of neo-prophetic churches, ${ }^{5}$ which are a development within the Pentecostal-Charismatic churches. These churches have their own expression of Pentecostalism. The neo-prophetic churches are succeeding in drawing large crowds with their emphasis on prophetic ministry (Omenyo \& Arthur 2013). Among some of the well-known neo-prophetic churches in South Africa are Enlightened Christian Gathering Church (ECG) led by Prophet Shepherd Bushiri (who also goes by the brand name, Major 1), Alleluia International Ministries (AIM) led by Pastor Alph Lukau, which recently made headlines with the saga of the miracle of a dead man's resurrection. ${ }^{6}$ The mushrooming of neo-prophetic churches is not limited to South Africa, but is evident across the African continent (see also Omenyo \& Atiemo 2006; Omenyo \& Arthur 2013).

In the neo-prophetic churches, the prophetic office and prophecy play a central role in the church. The role of prophecy in neo-prophetic churches, however, should not be confused with that in the African Initiated Churches (AICs) such as the Zionist and Apostolic churches in which prophetic ministry is done by those who have the gift to do so and is not limited to the church leader. For example, in the Zion Christian Church (ZCC), prophecy is a ministry of mabone [the lights] - prophets or seers - who receive revelations about people's circumstances and issues such as marital problems, family conflicts, misfortune, sorcery, witchcraft and sickness (Anderson 1999; Oosthuizen 1992). As Anderson (1999:299) notes, in this context, to prophesy is 'to pass on to others revelations or messages based upon what has been seen or heard through the special work of the Spirit'. The personal prophetic utterances to individuals are often offered in private. The prophetic activities in AICs are also closely linked to healing practices following ditaelo or ndaela [directives or orders] given to the sufferers; these are less instant miracles rather than they are processes.

The exponential growth of the neo-prophetic churches has created the perception that churches are becoming lucrative businesses for some who want to use the establishment of churches as a means of making money. The CRL Commission (2016) also notes that the practice of prophets or pastors getting money for performing things such as miracles and healings has raised concern within the South African society as to whether churches are becoming commercial institutions to enrich the few.

The neo-prophetic churches have, as a key feature, an emphasis on the divine power that resides in the person: the

5.Other tend to use the term neo-Pentecostal churches (see Kgatle 2017). In this article, the preferred term is neo-Prophetic churches.

6.While the two mentioned churches are led by foreign nationals, it should not be taken as implying that prophetic churches are simply run by foreign nationals. There are also many such churches run by South Africans. 
prophet - the person in whom resides the ability to prophesy, heal, deliver and pronounce blessings. Therefore, what is becoming prevalent through the neo-prophetic churches is the person-centred pilgrimage instead of the place-centred pilgrimage (see also Eade \& Sallnow 1991; Ramantswana 2018). Thus, it is not surprising that churches such as ECG and AIM can draw crowds from all over South Africa and abroad. Furthermore, others from South Africa are willing to make their pilgrimage to other countries for a spiritual encounter with the 'man of God' or 'woman of God' - the prophet. For example, on a weekly basis, South Africans travel to Nigeria for a spiritual encounter with the prophet T.B. Joshua. The pulling factor is the people's or believers' desire to experience a fresh divine word for their lives and experience divine power as channelled through the prophet.

Some of the key characteristics of the neo-prophetic church are the following: Firstly, it elevates the office of the prophet. The title prophet, as Omenyo (2011:41) notes, 'assume a new importance and significance'. Pastors now prefer to regard themselves as having a prophetic gift. In the prophetic churches, things tend to revolve around the prophet who, in most cases, is also the founder of the church.

Secondly, it dedicates time to prophecy in the liturgy or church proceedings. The prophets would, during the service, take the time to prophesy. This is often accompanied by the shouts from the congregants: 'Prophesy, man [or woman] of God!', or just 'Prophesy!' The prophecies made vary in their nature.

Prophecies tend to relate to people's lives. Therefore, many gravitate towards the prophets, because they are longing for a prophetic word which speaks to their own lives or circumstances. These are people who come with personal struggles, seeking divine intervention. To assure audience of prophetic reliability, there is a tendency of asking the person being prophesied questions such as, 'Have I ever met you before?', or 'Have I ever seen you before?' Other people, however, present themselves to the prophets with placards stating their problems so that the prophet bring about the necessary intervention, while others come not so much for themselves, but for their family members.

Predictive prophecies feature in various ways: (1) Predictions of something that will happen or is about to happen: if what is predicted happens, this becomes a valuable marketing tool to prove the authenticity of the prophet; (2) Predictions relating to well-known figures and high-profile people such as kings, presidents, political figures, sports stars and business people: these high-profile people are attracted to the prophets, probably in search of a sense of security, protection and good fortune; (3) Predictions relating to sports results and elections: if the prophet can predict sports or games results, it does not only boost the prophet's profile, the people will likely believe that they can also influence how things turn out in the future.

Thirdly, the neo-prophetic church allows the prophet to act as a channel for deliverance from demons or evil forces. It is quite common to see the prophet confronting demons during a church service, as the demons manifest themselves. In so doing, modern-day prophets see themselves as following in the footsteps of Jesus. The words of Jesus, evoked in John 14:12, are evoked as a lynchpin:

I tell you the truth, anyone who has faith in me will do what I have been doing. He will do even greater things than these, because I am going to the Father.

Fourthly, it has the prophet acting as a healer. The prophets also display divine power through healing various forms of diseases, sickness, paralysis, barrenness, et cetera. Where the physical evidence of diseases and sickness would not be visible, there is usually testimony times for those who have been healed or received their miracles. In some instances, doctors' notes are presented to authenticate the healing, while in other instances, people who are said to be doctors would be there to affirm the healing claims.

Fifthly and finally, it has prophets as channels of blessing and prosperity. The prophets pronounce blessings and good into the lives of people - a season of plenty, prosperity, good health, business success or healing to which the audience responds by saying, 'I receive', or whatever formula is used in the particular church.

Neo-prophetic churches tend to focus on the individual as a recipient of the prophetic utterance. The emphasis is on individual needs and interests - personal salvation. In the face of the poverty, economic hardship, low quality of life, lack of services, poor public health system and social hardship, which characterise the African context, these churches are succeeding to draw large crowds. As Chitando and Biri (2016) note, the men and women of God see themselves as charged with the mission of eliminating all forms of suffering and empowering the people of God to experience health and well-being'. Daswani (2015:114), reflecting on the prophetic movement in the Ghanaian context, writes:

Prophets act as spiritual brokers to link the market economy and economy of things with the spiritual world and the wider desires and ambitions of Ghanaians. It is in the efficacy of the words that the prophets utter, in their actions of prayer, and in the sacred things that they pray over and distribute that people come to believe that their economic realities change for the better and that 'God is there' ('Onyame ho wo') - with the prophet or in the place where the prophet operates. Through their prayers and prophecies, prophets connect those 'without' with what they need or desire, transforming value across different realms - converting culturally recognizable spiritual power into economic power.

Daswani's observation regarding the Ghanaian context also holds for the South African context.

People are attracted to the prophets, because they long for a personal divine word. Therefore, the prophetic utterance tends to be personal and does not concern so much the community at large. The neo-prophetic churches with the emphasis on prophetic ministry, are yet inwardly focused. The philanthropic activities are sometimes done by the neo- 
prophetic churches or the prophets towards the community. While they are positive gestures of service, they, however, do not amount to challenging the structural patterns and the system, which continue to keep the African people in the zone of damnation.

Dube (2015), reflecting on the Zimbabwean context, describes how the church has contributed to the pacification of the people: it has lured them into political disengagement. The purpose of the power dynamics in the churches is not confronting the political powers. The prophets, instead of confronting the oppressive force in society (the government that fails to provide services necessary to overcome the socioeconomic challenges), redirect the people to themselves. Consequently, people have no choice but to blame themselves for the social and political ills emanating from a corrupt government. Instances of government prosecution of the neo-prophets do not occur because their prophetic voice is challenging the government, but for corrupt activities. In the South African context, the recent trial of pastor Timothy Omotoso for charges of rape and human trafficking, and of the prophet, Shepherd Bushiri, for charges of fraud and money laundering as well as the investigation into the alleged resurrection of a dead man by pastor Alph Lukau, are typical examples of the prosecutions that the neo-prophets are now facing.

The neo-prophets with large groups of followers are well positioned to champion the struggle for a just and equitable society. They should not be simply fostering self-centred salvation, personal health, freedom and prosperity while the majority of people still linger in poverty, are jobless and die from curable diseases due to the poor health sector, and risk to loose their lives and properties due to high crime levels.

\section{Neo-prophets: Are they praying for, or preying on people?}

When the prophets pray for the people, make prophetic utterances, display divine power that brings about economic empowerment of the people and deliverance from various other forms of suffering, they also benefit economically in the process, as the people give money and offerings to the prophet or his or her ministry. Furthermore, the prophets have turned commodities such as stickers, oil, bangles and water into sacred objects that offer people divine protection against demons and forces of evil, and transmit spiritual blessings.

The prophetic promises are not without problems. The CRL Commission deems it worrisome for churches or prophets to advertise miracles, healing and prosperity and yet not be held accountable (CRL Commission 2016). In my view, the promises of prophetic utterances - healing, miracles, deliverance, prosperity and blessings on a daily and weekly basis - put the prophets under immense pressure to meet those promises and expectations. This, unfortunately, opens room for the exploitation of faith on the part of the people and believers who follow such prophets. The temptations of the prophets are twofold: to engage in acts of deception, rehearsed prophetic utterances and orchestrated miracles and healings, as well as to source powers from traditional healers (see also Lindhardt 2014). In his recent book, Church Mafia: Captured by secret powers: An untold African narrative, Ramabulana (2018), a pastor who has been tempted to obtain the sourcing powers of secretive and occultic practices, reveals how some of the (false) prophets operate within occult syndicates that keep them in operation using occultic powers and fake prophecies, healings and miracles. For Ramabulana, it was the frustration and pressure he faced in trying to get the church to grow that led him into operating as a false prophet.

The recent resurrection scandal, which occurred on 24 February 2019 at AIM, is but one example of the extent to which pastors or prophets are willing to go to, to display themselves as powerful. Following this scandal, it also emerged that people are recruited for fake healings, prophecies and miracles. When incidents of false prophecies, healings and miracles emerge, this should be viewed not as a prophetic activity, but as preying on people's faith. When false prophets pray for the people, they in fact, are preying on people's faith.

Furthermore, in our current culture of consumption, people tend to view religion as a commodity, and they are willing to purchase or spend towards it just as they do towards other products. Whether the quality is perceived or objective, once the customer is convinced of the service or the product, which the church, or else the prophet or pastor is offering, there is a willingness to pay or give more towards the church. In the South African context, free service and products are usually equated with poor service and products, and it is not surprising that such a mentality is also applying in the church context. This is exacerbated by the prophetic calls to sow the seed in faith so that there will be an overflow of blessings in the form of health, protection over one's material possessions, release from the curse of poverty, financial breakthrough, flourishing of business and an increase in material wealth. In this context of prophetic churches, poverty is prophetically proclaimed as a curse that needs to be broken (see Mahohoma 2017).

As prophets function as mediators of health, protection, wealth and prosperity, they come in the process, to accumulate gifts and money, which assumes that some become rich and now live luxuriously. As Daswani (2015:115) highlights, inasmuch as the role of the prophet may be deemed as a calling from God, it cannot be entirely divorced from the 'ethic of self-interest', as the prophet stands to profit from the performance of his or her spiritual actions. This also goes with biblical admonitions: 'Do not muzzle an ox while it is treading out the grain', and 'The worker deserves his wages' (1 Tm 5:18; cf. Dt 25:4). That said, some of the prophets are spiritual entrepreneurs who prey on people's faith in order to enrich themselves.

When prophets prey on people's faith, it is clergy malfeasance - commonly defined as misconduct of church officials such as prophets or pastors who intentionally 
commit illegal acts. However, this is hard to prove. Van Eck and Van Twist (2014:5) note:

As a white-collar crime, clergy malfeasance involves persuasion and guile, and often the process is open to ambiguity - it is not entirely clear that whatever is happening is fraudulent. This is either because the victims are often unaware that fraud has taken place or that their contributions were used for other purposes, or they may see the process in a favourable light because of the context in which it occurs.

For false prophecies and fake miracles and healings to go undetected by faithful followers, it mainly depends on the 'inner circle' of the prophet (Folk 2014:46). These are the people who cooperate with the prophet in order to facilitate the deception. In the case of fake miracles, people are recruited and paid to be participants. Thus, anyone involved in the deception, whether part of the inner circle, a recruited participant or a knowing spectator, is guilty of deception. The reluctance of these people to challenge their prophet or leader, as Folk (2014:46) points out, reflects an environment of 'enforced misrepresentation'. The challenge inherent in dealing with such deceptions is that they are often camouflaged and blended with half-truths, especially in the context of claims of prophetic utterances, healings and miracles.

When the false prophet is exposed as a con artist or fraudster, the fraudster and the followers will attempt to latch on to the ambiguity of the deception, to justify it through theological explanations or to brand the exposers as instruments of the enemy in a spiritual attack. Followers on the other hand, are more inclined to support their prophet. In the current climate where the prophet or pastor is regarded as a spiritual father, a daddy or a person sent by God, turning against him becomes an act of betrayal. Therefore, followers are more inclined to support their prophet. However, there are times when followers do recognise the deception, but they choose to remain silent or to walk away quietly in fear of their lives. In cases of members choosing to remain, as Folk (2014:49) notes, '[a] mixture of emotions, including adulation, a desire to please, and fear of supernatural powers might keep members from speaking out'.

Prophetic ministry, rather than simply serve the personal needs of believers or enhance the status of the prophet, has to be perfomed from the position of vulnerability. Being vulnerable implies opening oneself to the societal issues that requires prophetic confrontation, as prophets stand againts injustice, exploitation, oppression and dehumanisation. In so doing, the prophetic ministry is performed in solidarity with the vulnerable of society (Vosloo 2019). As Vosloo (2019:5) puts forward, the church's prophetic ministry has to 'name and resist the forces of dehumanisation, oppression and injustice'. Thus, prophetic ministry should have, as its preferential option, the vulnerable of society and not the self-interest of the seekers of the prophetic utterances driven by individualism, consumerism and aggrandisement of the prophets who are urged by personal desires and ambitions to be prosperous and great prophets.

\section{Conclusion}

The Pentecostal-Charismatic view of prophetic ministry is different from the traditional understanding that associates prophecy with the general ministry of every believer and the proclamation of the gospel as well as the ecumenical church's understanding that views prophetic ministry as a critical engagement with socio-political issues in the struggle for justice. The Pentecostal-Charismatic view regards prophetic ministry as a gift that is linked to direct revelation from. In the classical Pentecostal-Charismatic view, this gift could be upon anyone without equating it or subsuming under the office of pastor. However, in neo-prophetic churches, the prophetic gift is centred around the person who, in most cases, is also the pastor. However, in this case, it is now the prophetic office that is the prevailing one with the pastoralteaching role subsumed under it.

The link between the office of Christ as a prophet and those of the believer as a prophet, has to inform our understanding of the function of the prophet's office, namely whether it is viewed as a universal office for every believer in the life of the church (mainline churches) or a mandate of the ecumenical church, or as a special office exercised by the chosen few (neo-prophetic church). As Rush (2003:151) argues:

... any retrieval of the notion of the prophetic office must be grounded on in a prophetic Christology that highlights who Jesus was as a prophet and how he understood and exercised his ministry of prophecy.

The climactic moment in the person of Jesus Christ did not render obsolete the OT prophetic tradition, which found its fulfilment in him; rather, in him the church received a fresh mandate to fulfil the prophetic ministry in the world. In the words of De Gruchy (2016:2), 'if Jesus is the prophet who is more than a prophet, the church cannot be less than a prophet in obeying him as Lord'.

The church lives out its role as a prophetic voice, carrying a double-edged sword. It has to do its work within the church as the body of Christ as well as in the society in which the church lives. The prophetic voice of the church cannot be limited to simply addressing the personal needs of individuals while leaving the structural issues in society unaddressed. Today's neo-prophets with their large numbers of followers, unlike before, are well positioned to mobilise their churches to be prophetic rather than to enjoy the limelight of being prophets while their churches play no prophetic role in society.

\section{Acknowledgement Competing interest}

I declare that I have no financial or personal relationship(s) which may have inappropriately influenced me in writing this article.

\section{Author contributions}

I declare that I am the sole author of this research article.

\section{Funding information}

This research received no specific grant from any funding agency in the public, commercial, or not-for-profit sectors 


\section{Data availability statement}

Data sharing is not applicable to this article as no new data were created or analysed in this study.

\section{Disclaimer}

The views and opinions expressed in this article are those of the author and do not necessarily reflect the official policy or position of any affiliated agency of the author.

\section{References}

AACC, 1975, The struggle continues: Official report, 3rd assembly of the all Africa Conference of Churches, Lusaka, Zambia, 12-24 May 1974, ACCC, Nairobi

Anderson, A.H., 1999, 'The Lekganyanes and prophecy in the Zion Christian church', JournalofReligioninAfrica29(3),285-312.https://doi.org/10.1163/157006699X00368

Beal, R.M., 2011, 'Priest, prophet and king: Jesus Christ, the church and the Christian person', in G. Mannion \& E. van den Borght (eds.), John Calvin's ecclesiology, pp. 90-106, T\&T Clark, New York.

Bentley, W., 2013, 'Defining Christianity's "prophetic witness" in the post-apartheid South African democracy', Studia Historiae Ecclesiasticae 39(1), 1-7. https:// www.scielo.org.za/pdf/she/v39n1/03.pdf

Chitando, E. \& Biri, K., 2016, 'Walter Magaya's prophetic healing and deliverance (PHD) ministries and pentecostalism in Zimbabwe: A preliminary study with particular reference to ecumenism', Studia Historiae Ecclesiasticae 42(2), 72-85. https://doi.org/10.17159/2412-4265/2016/829

CRL Commission, 2016, CRL Rights commission's preliminary report of the hearings on the commercialisation of religion and abuse of people's belief systems, 01 May 2019, viewed from www.crlcommission.org.za

Daswani, G., 2015, 'A prophet but not for profit: Ethical value and character in Ghanaian Pentecostalism', Journal of the Royal Anthropological Institute 22(1) 108-126. https://doi.org/10.1111/1467-9655.12336

De Boer, E.A., 2013, 'Christology and Christianity: The theological power of the threefold office in Lord's Day 12', In die Skriflig 47(2), Art. \#682, 8 pages. https:// doi.org/10.4102/ids.v47i2.682

De Gruchy, J., 2016, 'Kairos moments and prophetic witness: Towards a prophetic ecclesiology', HTS Theological Studies 72(4), a3414. https://doi.org/10.4102/hts. v72i4.3414

De Kruijf, G.C., 1994, Waakzaam en nuchter: Over Christelijke Ethiek in een Democratie Ten Have, Baarn.

De Villiers, E., 2010, 'Prophetic witness: An appropriate mode of public discourse in the democratic South Africa?', HTS Theological Studies 66(1), Art. \#797, 8 pages. https://doi.org/10.4102/hts.v66i1.797

Dube, Z., 2015, 'Jesus and Afro-Pentecostal prophets: Dynamics within the liminal space in Galilee and in Zimbabwe', HTS Theological Studies 71(1), Art. \#2748, 6 pages. https://doi.org/10.4102/hts.v71i1.2748

Dunn, P.J., 2016, 'Prophets, Faust, and first-years: Bonhoeffer and the language of charismatic experience', Stellenbosch Theological Journal 2(2), 39-56. https://doi. org/10.17570/stj.2016.v2n2.a02

Eade, J. \& Sallnow, M.J., 1991, 'Introduction', in J. Eade \& M.J. Sallnow (eds.) Contesting the sacred: The anthropology of Christian pilgrimage, pp. 1-29, Wipf \& Stock, Eugene, OR

Folk, H., 2014, 'Minority religions and fraud: Preliminary theories on ritual deception', in A. van Eck \& D. van Twist (eds.), Minority religions and fraud in good faith, pp. 35-52, Ashgate, Farnham.

Gee, D., 1972, Concerning spiritual gifts, Gospel Coaliation, Springfield, MA.

Grudem, W., 1999, The gift of prophecy in 1 Corinthians, Wipf \& Stock Publishers, Eugene, OR.

Kasper, W., 1988, Theology and church, Crossroads, New York.
Kaunda, C.J., 2018, 'The day of prayer and its potential for engendering public ecclesiology ecumenism in Zambia', Religions 9(12), 1-13. https://doi. org/10.3390/rel9120393

Kgatle, M.S., 2017, 'The unusual practices within some neo-Pentecostal churches in South Africa: Reflections and recommendations', HTS Theological Studies 73(3), a4656. https://doi.org/10.4102/hts.v73i3.4656

Kgatle, M.S., 2018, 'The prophetic voice of the South African Council of Churches: A weak voice in post-1994 South Africa', HTS Theological Studies 4(1), a5153. https://doi.org/10.4102/hts.v74i1.5153

Leonard, G.S.D., 2010, Kairos documents, Ujamaa Centre, Pietermaritzburg, viewed 01 May 2019, from https://ujamaa.ukzn.ac.za/Libraries/manuals/The_Kairos_Documents. sflb.ashx

Li Ming Dennis, L., 2018, The practice of prophecy: An empirical-theological study of Pentecostals in Singapore, Wipf \& Stock Publishers, Eugene, OR.

Lindhardt, M., 2014, 'Miracle makers and money takers: Healers, prosperity preachers and fraud in contemporary Tanzania', in A. van Eck \& D. van Twist (eds.), Minority religions and fraud in good faith, pp. 166-167, Ashgate, Farnham.

Mahohoma, T.C., 2017, 'A theological evaluation of God business: A case study of the prophetic healing and deliverance ministries of Zimbabwe', HTS Theological Studies 73(2), a4529. https://doi.org/10.4102/hts.v73i2.4529

Oliveanus, C., 1995, A firm foundation: An aid to interpreting the Heidelberg Catechism, transl. L. Bierma, Baker Books, Grand Rapids, MI.

Omenyo, C.N., 2011, 'Man of God, prophesy unto me: The prophetic phenomenon in African Christianity', Studies in World Christianity 17(1), 30-49. https://doi. org/10.3366/swc.2011.0004

Omenyo, C.N. \& Arthur, W.J., 2013, 'The Bible says! Neo-prophetic hermeneutics in Africa', Studies in World Christianity 19(1), 50-70. https://doi.org/10.3366/ swc.2013.0038

Omenyo, C.N. \& Atiemo, A.O., 2006, 'Claiming religious space: The case of neoprophetism in Ghana', Ghana Bulletin of Theology, New Series 1(1), 55-68.

Oosthuizen, G.C., 1992, The healer-prophet in Afro-Christian churches, Brill, Leiden.

Palma, A.D., 1970, 'The gift of prophecy: It's nature and scope', Paraclete 4(3), 8-13.

Pannenberg, W., 1977, Jesus-God, 2nd edn., transl. L.L. Wilkins \& D.A. Priebe, Westminster Press, Philadelphia, PA.

Ramabulana, M.K., 2018, Church Mafia: Captured by secret powers: An untold African narrative, Makhado Freedom Ramabulana, n.p.

Ramantswana, H., 2018, 'From the blood of Abel to the blood of Zechariah to the blood of the victims who died at SCOAN: A critical reflection', in M. Masenya (Ngwan'a Mphahlele) \& K.N. Ngwa (eds.), Navigating African biblical hermeneutics: Trends and themes from our pots and our calabashes, pp. 103-120, Cambridge Trends and themes from our pots
Scholars Publishing, Newcastle.

Resane, K.T., 2017, 'The church's prophetic role in the face of corruption in the South African socio-political landscape', Pharos Journal of Theology 98(1), 1-14.

Resane, K.T., 2018, 'Ichabod - The glory has departed: The metaphor showing the church's prophetic failure in South Africa', Pharos Journal of Theology 97(1), 1-12.

Rush, 0., 2003, 'The offices of Christ, Lumen Gentium and the people's sense of the faith', Pacifica 16(2), 137-152. https://doi.org/10.1177/1030570X0301600202

Sherman, R., 2004, King, Priest, and Prophet: A trinitarian theology of atonement, T\&T Clark, New York.

Snyman, S.D., 2016, 'What happened to the prophets in South Africa since 1994?', in R. Venter (ed.), Theology and the (post)apartheid condition: Genealogies and R. Venter (ed.), Theology and the (post)apartheid conditio
futurections, pp. 88-105, SUN MeDIA, Bloemfontein.

Stewart-Sykes, A., 2001, Hippolytus: On the Apostolic tradition: An English version with introduction and commentary, St. Vladimir's Seminary, Crestwood, MO.

Strydom, J.G., 1997, “"Where have all the prophets gone?" The New South Africa and the silence of the prophets', Old Testament Essays 10(3), 494-510.

Strydom, J.G., 2000, 'Being a prophet in the New South Africa: Can we learn from the Old Testament prophets?', Old Testament Essays 13(1), 103-118.

Van Eck, A. \& Van Twist, D., 2014, 'Introduction', in A. van Eck \& D. van Twist (eds.), Minority religions and fraud in good faith, pp. 1-15, Ashgate, Farnham.

Vosloo, R., 2019, 'Prophetic witness in weakness', In die Skriflig 53(4), a2400. https:// doi.org/10.4102/ids.v53i4.2400

Warrington, K., 2008, Pentecostal theology: A theology of encounter, T\&T Clark, London. 